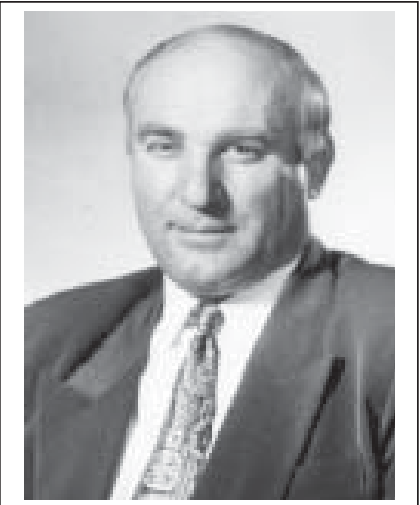

В.Д. Дзидзоев

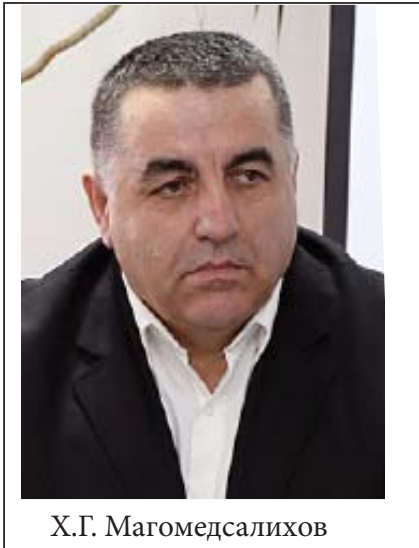

Х.Г. Магомедсалихов

\title{
СПЕЦИФИКА ГРАЖДАНСКОЙ ВОЙНЫ И СОВЕТСКОЙ МОДЕРНИЗАЦИИ В ДАГЕСТАНЕ
}

\author{
В.Д. Дзидзоев, Х.Г. Магомедсалихов ${ }^{* *}$
}

\begin{abstract}
Аннотация. Октябрьская революция 1917 г. и последующая социально-экономическая и политическая модернизация в Дагестане имели свои специфические особенности, обусловленные локальными причинами и фракторами. Гражданская война здесь носила затяжной характер и явилась острым социальным конфрликтом. Советская модернизация сопровождалась политическими репрессиями.

Ключевые слова: Дагестан, революция, гражданская война, антисоветское восстание, советская модернизация, коллективизация.
\end{abstract}

Революции наряду с другими социальными катаклизмами - войнами, восстаниями, бунтами, социально-экономическими кризисами и т. п. - представляют собой острые и резонансные конфликты, безусловный конструктивный потенциал которых в том, что они выполняют роль локомотивов в социальном прогрессе. Такие катаклизмы представляют собой радикальный путь, альтернативой которому является эволюционный.

Самым масштабным катаклизмом в XX в. явилась Октябрьская революция 1917 г. в России, которая имеет эпохальное значение, так как повлияла на последующий ход мировой истории и до настоящего времени оказывает влияние на локальные и мировые процессы. Она явилась эрой альтернативного понимания социально-экономического мироустройства, стала экспериментом по достижению социальной справедливости на основе экспроприации собственности у имущих и равного ее перераспределения. Практика Октябрьской революции базировалась на марксистском, материалистическом понимании истории, которая в основу социального прогресса и справедливости ставила классовый антагонизм.

Марксистская модель социальной истории воплощала в себе многовековые чаяния большинства человечества о социальной справедливости, она не потеряла актуальности до настоящего времени, в связи с чем гуманитарные науки, в числе которых история, призваны представить научно обоснованную интерпретацию Октябрьской революции 1917 г. и обусловленных ею последующих событий.

Несмотря на то, что Октябрьская революция проводилась по единому сценарию, в регионах она коррелировала с локальной социальноэкономической спецификой. Не исключение в этом отношении также Дагестан.
Важной специсической чертой Дагестана было то, что область значительно отставала от центральных промышленных регионов России по уровню социально-экономического и культурного развития. Около 40 \% территории Дагестана составляла плоскостная часть, с соответствующим числом населения. А около 60 \% территории были горы, и горцы имели отношение к промышленности только через сезонных работников. В горной части до Октябрьской революции 1917 г. не зафиксировано ни одного промышленного предприятия. Как правило, промышленность сосредотачивалась в городах, которых в Дагестане к 1917 г. было всего три - Дербент, Порт-Петровск и Темир-Хан-Шура. В 1913 г. численность населения составляла 707950 чел., из которых 78 427, или же $11 \%$, жили в городах [12, с. 79], в том числе в Темир-Хан-Шуре - 20 836 и Порт-Петровске - 24037 [12, с. 80].

Численность всего рабочего сословия накануне революции в Дагестане составляла около 4000 чел., и самым крупным предприятием в области была текстильная фабрика «Каспийская мануфактура» в Порт-Петровске, где было занято в разное время от 400 до 1000 человек [12, с. 93]. Все остальные предприятия были мелкие, на них было занято в среднем по 5-7 человек. Из-за малочисленности и разрозненности рабочее сословие не могло представлять угрозы существующему строю. Поэтому для Дагестана наряду с некоторыми областями России после революции 1917 г. актуальным стал вопрос о возможности перехода к социализму, «минуя капиталистическую стадию».

Уровню экономического развития соответствовали социальная структура и общественные отношения. Что касается сельского населения, то в горах основным сословием были независимые уздени и отсутствовала эксплуатация. У равнинных

"Дзидзоев Валерий Дударович - д. и. н., профр., гл. н. с. ВНЦ РАН , зав. кафр. Горского ГАУ, г. Владикавказ (dzidzoevv@mail.ru).

Магомедсалихов Хайбула Гамзатович - д. и. н., в. н. с., Институт истории, археологии и этнографии Дагестанского НЦ РAH, г. Махачкала (Haibula45@mail.ru). 
народов имела место социальная градация, но и здесь не было более или менее выраженного сословного антагонизма. В источниках и литературе относительно дореволюционного периода не зафиксировано ни одного случая сословного антагонизма с летальным исходом.

Чтобы обосновать идею классового антагонизма в дореволюционном Дагестане, в литературе советской эпохи в угоду идеологии приводятся стереотипные сюжеты вроде нижеследующего. 5 октября 1917 г. «помещик» Мамерзабек Табасаранский телеграфно сообщил областному комиссару, что «жители сел. Марага... захватили» его кутан, «водворились на нем», и просил оградить имущество от насилия и произвола $[4$, с. 34]. Но этот фракт и множество подобных имеют идеологическую подоплеку и не являются вескими основаниями и убедительными доводами в пользу классового антагонизма и не объясняют причину революции и затем гражданской войны. Тем более, что в продолжение всей истории в горах Дагестана имели место дефицит земли и конфликты на этой почве, но никто их не интерпретирует как обусловленные классовым антагонизмом.

Дефицит материальных ресурсов в Дагестане усугубился после революции, чем была обусловлена острота социального конфлликта в обществе. Не зря один из лидеров контрреволюции Н. Гоцинский с самого начала в свой отряд привлекал горскую бедноту, обещая грабеж. Так, очевидец событий Ибрагим Махмудов в своих записках о вторжении Н. Гоцинского в Порт-Петровск в апреле 1918 г. писал: «Самое замечательное у имамовцев - это были порожние хурджины на плечах. Гоцинский обещал своим войскам разрешить грабеж. Когда весною 1918 г. имамовцы ворвались в Порт-Петровск, то сейчас же многие, бросив оружие, приступили к грабежу. <...> Многотысячное «войско» имама пробыло в городе около одной недели. Имамовцы разграбили все, что можно было разграбить и разбрелись по домам» [8].

Кстати, контрреволюционные отряды Н. Гоцинского в этом походе потерпели поражение, погибло более тысячи человек, среди которых были представители едва ли не всех дагестанских селений. «Тысячи вдов и сирот во всех аулах Дагестана проклинали имя Гоцинского. Не было аула, откуда бы не было хотя бы одного-двух убитых в петровском поражении» [8]. Таков был один из первых печальных итогов исламской консолидации, которая впоследствии переросла в более масштабный и острый социальный конфликт - антисоветское восстание.

Другая важная особенность советской модернизации была обусловлена религиозным фактором, который в других регионах Северного Кавказа не стоял так остро, как в Дагестане. Тем более что советская власть с самого начала не скрывала своего враждебного отношения к религии, называя ее «сердцем бессердечного человека», «опиумом для народа», «вздохом угнетенной твари» (К. Маркс). В ответ на это с первых лет мусульманское духовенство активно саботировало Советскую власть, распространяло слухи о том, что якобы где ступит нога большевика, там засыхает трава [23]. Сила влияния мусульманского духовенства на массы в Дагестане как до, так и после революции была высокой, и не зря лидеры контрреволюции привлекали на свою сторону горскую бедноту, спекулируя на их религиозных чувствах: «... Нажмудин внушал массам через свой агитпроп - мулл, шейхов, что каждый, кто откажется от участия в движении по созданию имамата, теряет свое «мусульманство». И люди шли: одних привлекала перспектива подработки, другими двигала боязнь оказаться вне «мусульманства» [25, с. 28-29]. А сподвижник Н. Гоцинского Узун-Хаджи, который по отношению к революции занимал крайне радикальную позицию, обещал повесить на одной веревке «всех, кто пишет слева направо - комиссаров, инженеров, учителей» [2, с. 87]. Здесь дефицит материальных благ и религиозный фактор тесно переплетались, чем активно пользовались лидеры контрреволюции, отдавая на грабеж непокорные поселения.

Следующей особенностью гражданского противостояния в Дагестане после революции было ущемленное национальное чувство значительной части дагестанцев и особенно горцев, когда в их сознании «царизм и колониальные порядки ассоциировались со всем русским народом» [16, с. 70]. Примечательно, что во время встречи в 1921 г. В.И. Ленин у дагестанской делегации спросил: «А все также ненавидят дагестанцы русских?» [26, с. 7]. Эти настроения наряду с религиозными чувствами лидеры контрреволюции Н. Гоцинский и Узун-Хаджи также использовали в своих интересах.

В основе гражданского противостояния на всем протяжении советской социально-экономической модернизации остро стоял вопрос о собственности и ее перераспределении, который в Дагестане имел свои особенности. Социалисты в этом вопросе занимали радикальную позицию в пользу ее экспроприации и национализации. Крупные собственники сразу же после революции передали все имущество Советской власти. Так, промышленник 3. Тагиев добровольно передал все свое имущество Советской власти, уехал в Азербайджан и в 1931 г. благополучно скончался. Другой крупный собственник М. Мавраев также передал все свое состояние новой власти, но в 1928-1929 гг. началась его травля, и, спасаясь от преследований, он скрылся в Акмолинске, проживал там под чужим именем и скончался в 1964 г. [15, с. 61]. В отличие от них крупный собственник-барановод Н. Гоцинский открыто встал против Советской власти и возглавил контрреволюцию. В 1925 г. отряд, который он возглавлял, был разгромлен, а сам Гоцинский арестован и расстрелян.

Отношение к земельной собственности в Дагестане было радикально другим, чем в центральных регионах России, так как традиционно земля представляла наивысшую ценность для горца, от нее 
зависел не только его социальный статус, но и само существование. Острый дефицит земли был причиной того, что горцы традиционно отождествляли личную свободу с земельной собственностью, на почве защиты границ которой в горах происходили кровавые распри.

Поэтому в отношении земельной собственности горцы строго стояли на позициях исламских традиций и адатных норм, когда частное свято оберегалось от посягательства. «Собственность на землю по представлению мусульман священна, а стало быть, и неприкосновенна» [28, с. 78]. Также вспомним об отношении горцев к частной собственности в XIX в.: «В книге сказано: умереть, защищая свою собственность, то же, что умереть шахидом (умершим в войне с неверными)» [20, с. 37]. Таким образом, шариат и адат строго стояли на страже частной собственности, и особенно на землю, а советская власть экспроприировала собственность, что заключало в себе значительный конфликтный потенциал.

Наряду с отношением к собственности неопределенность в обществе была обусловлена наличием нескольких правовых систем, регламентирующих социальные отношения, в числе которых были нормы обычного права (адаты), религиозные предписания - шариат, а с конца XIX в. в общественное сознание горцев активно внедрялись российские законы. К тому же бытовые отношения регулировались традиционными морально-этическими нормами, что в совокупности представляло правовую неопределенность. Как следствие этого, в республике в 1925 г. было зарегистрировано 219 убийств, а в следующем году - 245. Основными причинами разгула уголовной преступности назывались «поголовное вооружение населения, некультурность и кровная месть» [22, л. 162].

В результате приведенных причин и сопутствующих им факторов гражданская война в Дагестане обрела продолжительный и ожесточенный характер. В литературе советской эпохи было принято считать, что гражданская война в Дагестане завершилась 30 марта 1920 г. Она имела тяжелые материальные, социально-экономические и морально-психологические последствия. В источниках и литературе отсутствуют сводные цифры о людских потерях в период гражданской войны, но и имеющиеся цифры красноречиво свидетельствуют о масштабах социального конфликта. Так, общий убыток, нанесенный интервенцией и гражданской войной Дагестану составил 26008059 тыс. рублей [13, с. 259].

Однако самый кровавый этап, который в литературе советского периода было принято называть «антисоветским мятежом Гоцинского» и который рассматривался вне хронологических рамок гражданской войны, был еще впереди. Антисоветское восстание происходило с сентября 1920 г. по март 1921 г. и было мотивировано политикой «военного коммунизма», которая после окончания гражданской войны продолжалась прежними темпами. Так. в докладной записке предревкома Гунибского округа о сборе продуктов у населения отрядом под руководством Шамхала Салихова от 10 октября 1921 г., отмечается: «... с отрядом в 120 чел. уже проехал 4 участка и направляется в пятый. Набрано 220 пудов ячменя, 230 пудов сена, 30 пудов мяса, 100 пудов ячменной муки, 15 баранов, 1 бык, 3 пуда сыру, 3 лошади и 50 тыс. рублей деньгами, сожжена Анцухская дорожная станция. Такого зверства население не видело даже при бандитах, отбиралось все до последнего - под угрозой расстрела, и не помогал плач женщин и детей. Зная крайнюю бедность населения, а также учитывая то, что сейчас в упомянутых участках (Анцух-Капучинском и Богнодальском) осталось незначительное число населения (остальное ушло в Грузию), я верю, что у населения были отняты последние пищевые продукты...» [24, с. 380-381].

Удручающее положение, обусловленное экономической диктатурой Советской власти, имело место также в Андийском округе, о чем в мае 1921 г. сообщалось в докладной записке чрезвычайного уполномоченного ревкома Дагестана по округу Д. Саидова: «За совершенным отсутствием какой-либо медицинской помощи в округе свирепствуют различные эпидемические заболевания, как-то тиф, оспа и т. п., ежедневно уносящие в могилу сотни бедняков, хотя приняты и принимаются всевозможные меры к очистке аулов от сора и зловонных предметов... Кроме того, развитию всевозможных болезней способствует фрорменный голод» [6, л. 1-7].

По поводу непомерно высоких налогов в период политики военного коммунизма представители горской бедноты высказывались на съезде 9 октября 1920 г. в Левашах, созванного специально для борьбы с антисоветским восстанием. Судя по распоряжению областного продовольственного комитета, «Даргинский округ в течение одной недели должен заготовить десять тысяч пудов ячменя, двадцать тысяч кусков шали, десять тысяч пудов саману и т. д.», и к тому же «продовольственный комитет велел взять на учет всех кур в Дагестане» [13, с. 99]. Съезд бедноты открыто выразил свое возмущение мероприятиями советской власти: «... Мы не требуем, чтобы нам послали помощь из Москвы или Питера. Дайте нам хоть то, что лежит под рукой. Почему нам не дают керосина? Мы знаем, что у нас на складах в Даргинском округе имеется и керосин и мануфактура. А когда мы просим, чтобы нам дали, нам отвечают: «предписано, пока не выполните наряда, не дадите требуемое количество скота, не получите ни одного фунта керосина, ни одного аршина мануфактуры». А где нам достать этот скот, где взять этих кур и масло, которое у нас требуется? Мы можем дать только свою кровь - и мы ее даем» [13, с. 99]. Изъятием «излишков» занимались представители социальных низов, полные решимости расквитаться за свой низкий статус с относительно зажиточными представителями, что было сопряжено с конфрликтами в обществе.

В рамках политики «военного коммунизма» в го- 
рах начался учет кур, яиц, масла. Приступили к национализации горских мельниц «величиной в хороший кулак и т. д. «Куриная власть», а не Советская, говорили крестьяне» [25, с. 142].

Однако справедливости ради следует отметить, что по Дагестану, в связи с переходом от продразверстки к продналогу («военный коммунизм»), собственно от налога было освобождено до 45 \% всех дворов, главным образом маломощных и бедняцких [5, с. 110]. Но и в этом случае горцы не были в состоянии удовлетворить минимальные свои материальные потребности, чем, в том числе, были обусловлены масштабы антисоветского восстания.

Наряду с экономическими мероприятиями восстание было вызвано жестокими мерами, применяемыми частями красной армии к местному населению. Так, по воспоминаниям жителя сел. Геничутль Магомеда Испагаева, в феврале 1921 г. за два дня отрядами Красной армии в ауле были перебиты 68 стариков, женщин и детей, а на третий день оставшихся в живых, благодаря вмешательству Муслима Атаева, выслали из села. Брать с собой ничего не разрешалось, а их дома были отданы на разграбление солдатам. Приказ А. Тодорского исполнял Н. Самурский [9].

Не менее одиозный случай имел место 11 марта 1921 г. в сел. Сиух Гумбетовского района. Отряды красной армии под командованием А. Тодорского во время пятничного намаза осадили мечеть и на выходе арестовали 27 на выбор молодых и крепких мужчин, которых взяли в заложники и предъявили заведомо невыполнимые требования: выдать 500 винтовок, 300 пистолетов и тех, кто воевал против красной армии на стороне Гоцинского. Пытавшегося объяснить ситуацию старшину села Абакар-Дибира Шуайбова расстреляли. Прямо на годекане были расстреляны 24 перевязанных заложника, а один, по имени Магомедсултан, который чудом уцелел, увидев, как расстреливают односельчан, бросился к сараю, взял припрятанную там винтовку, убил командира и еще 5 красноармейцев, но и сам был убит шквальным пулеметным огнем. Командованием отряда было принято решение в течение двух часов расстреливать обнаруженных сивухцев и всего было расстреляно 132 человека, в том числе женщин, детей, стариков [24. с. 376-377].

В основе гражданского противостояния с самого начала советской власти были две главные проблемы: а) отношение к собственности и б) роль ислама в будущем обществе. В этих вопросах советская власть и мусульманское духовенство стояли на непримиримых позициях. Этим, в том числе, объяснялись широкие масштабы гражданского противостояния и острота социального конфлликта в период антисоветского восстания и последующей советской модернизации.

О масштабах восстания и остроте противостояния в период «антисоветского мятежа» может свидетельствовать выдержка из доклада Кавбюро РКПб от 3 января 1921 г.: «Восстание, охватывающее в настоящее время почти 2/5 Дагестана, длит- ся уже 2,5 месяца. Теперь восстанием охвачены округа Аварский, Гунибский, Андийский, Казикумухский, часть Даргинского, по всей вероятности, при дальнейших успехах повстанцев район восстания будет расширяться» $[14$, л. 18]. Об этом же свидетельствует один из руководителей контрреволюции полковник М. Джафаров: «Вначале большинство населения аварских округов было на стороне восставших. Почти во всех аулах нас встречали не только радушно, но и с большим энтузиазмом. В каждом почти ауле к нам присоединились отряды добровольцев, готовые нести за свой счет и риск все тяжести борьбы со строем, который сразу показал себя им определенно враждебным» [7, л. 65]. В начале ноября 1920 г. повстанцы насчитывали В своем составе до 10 тыс. человек [10, с. 107].

Противостояние порою доходило до ожесточения, которого не знали в течение предшествующих трех лет. Так, в боях в Араканском ущелье в конце октября 1920 г. по сведениям командира красной армии А. Тодорского только со стороны красноармейцев погибло до 700 чел., захвачено 24 пулемета, 4 орудия и много патронов [27, с. 82]. Аналогичный кровавый эпизод с большими человеческими жертвами имел место 18 ноября 1920 г., когда повстанцы в районе селений Муни-Орто-Коло окружили и полностью перебили значительные силы революционного полка [10, с.114]. Эпизодов с меньшими человеческими жертвами было гораздо больше.

Итак, восстание в Западном Дагестане было обусловлено рядом причин и факторов, в числе которых экономические мероприятия органов советской власти и карательные действия частей красной армии были основными. Эти же причины обусловили политический бандитизм, который сложился в период гражданской войны и которым сопровождались другие мероприятия советской власти, в том числе коллективизация.

О масштабах политического бандитизма могут свидетельствовать следующие цифры. После гражданской войны в Анцухо-Капучинском участке Гунибского округа действовала банда численностью 670 человек под руководством шейха Ибрагим-Хаджи. В Хасавюртовском округе действовала бандитская группа Алишапи, в Махачкалинском участке и Дербентском округе население терроризировали банды Бабы и Джангира, в Аварском округе - банды Гамзат-Турка и Гоцатль Джамала, в Самурском округе - бандитская группировка Рамзана Эфендиева [22, л. 149].

Как отмечалось, отношение к собственности и религии были принципиально противоположными между социалистами и контрреволюционерами. Идея экспроприации частной собственности и искусственное ее перераспределение в пользу неимущих как основная суть советской социальноэкономической модернизации особенно наглядно выразилась в процессе коллективизации и заключала в себе конфлликтный потенциал между значительной частью общества и политической системой. 
Экспроприация собственности противоречила одному из базовых принципов человеческого мировоззрения. Недаром все мировые религии и известные в истории политические системы стояли на страже частной собственности. В одном из антисоветских воззваний мусульманского духовенства к населению говорилось: «Эй, мусульмане! Наступает «ахират» (конец света. - В.Дз., Х.М.). Большевики не признают бога, не признают семьи и частной собственности, не позволяют молиться. К чему же нам жить, о мусульмане...» [3, с. 568]. Поэтому сама идея коллективизации изначально противоречила сложившимся стереотипам мышления и ментальным особенностям горцев и потому к экспроприации земли значительная часть горцев отнеслась с большим недоверием и антипатией, а зажиточная часть - враждебно.

В антиколхозной агитации духовенство использовало религиозные чувства верующих. Так, в с. Великент Дербентского района духовенство распускало слухи, что колхозникам будет запрещено верить в Бога, в колхозе жены и дети будут общими, хлеб будет выдаваться из общей пекарни, колхозникам запретят печь хлеб дома [21, с. 182]. Тем самым духовенство находило самые чувствительные мотивы, чтобы настроить население против мероприятий советской власти, за что оно было поголовно репрессировано. В одном только райцентре Цумадинского района Хуштада в 30-40-х гг. погибло от репрессий около 60 чел., в том числе 35 - в 1928-1939 гг. Сильнее всего хуштадинцев потрясла гибель в 1930 г. в НКВД известного шейха накшбандийского тариката Хусейна Пирмагомедова [1, с. 20].

Большевистская идеология, основанная на классовом антагонизме, стала основным инструментом изменения массового сознания в русле преданности политическим идеалам. Массовые преследования и репрессии проводились по имущественному цензу и идеологическим (политическим) мотивам. На почве конфискации собственности у зажиточных представителей и ее перераспределения в пользу неимущих в обществе проводилась всеобщая уравниловка в бедности.

Особенно упорное сопротивление мероприятиям по коллективизации наблюдалось в Цумадинском районе и Дидоевском участке, где движение приняло массовый характер. О беспорядках в Цумадинском районе ДАССР от 12 марта 1930 г. в документе отмечалось: «В аулах Хуторок, Шаитль, Шаури на собраниях под давлением арабистов и кулаков вынесены постановления, предлагающие коммунистам, совработникам удалиться из Дидоевских аулов и больше не появляться: «Дайте нам жить, как жили при Николае» [18, с. 146]. То есть население выступало не просто против колхозов, а против советской власти вообще.

500 человек горцев Цумадинского района и Дидоевского участка поклялись на Коране не вступать в колхоз и «дали клятву бороться до последнего под фрлагом шариата» [11, л. 164]. Повстанцы захватили ряд аулов: Кидеро, Шаури, Тлясута, Шаитль, Генух,
Мокок, Цибари, Ицрак и прилегающие к ним хутора с центром в селении Шаури.

С самого начала по всей стране «репрессии на селе были составной частью системы государственного управления сельским хозяйством» [19, с. 95-96] и насильственная коллективизация лишала предприимчивости сельхозпроизводителя. Как правило, в числе «кулаков» оказывались наиболее деятельные и предприимчивые сельхозпроизводители, которых репрессировали только за предпринимательскую активность.

В целях повышения колхозного производства советской властью были введены новые методы стимулирования в виде социалистических соревнований, досок почета, поощрительных грамот, переходящих знамен и т. д. Однако эти меры были рассчитаны на энтузиазм, они подменяли рыночные механизмы, имитировали конкурентную борьбу. В условиях отчуждения собственности личный интерес и стимул производителя к результатам труда упал.

Коллективизация как новая система вначале имела определенные успехи. Она подняла на некоторое время моральный дух определенного числа горцев, вдохнула веру и надежду в торжество социальной справедливости. Однако последующий опыт показал, что через экспроприацию собственности и его равное распределение социальная справедливость не достигается.

Социально-экономическая модернизация в Дагестане, как и по всей стране, проводилась в условиях идеологического прессинга, что предусматривало насилие и антагонизм по отношению к политическим оппонентам в лице всех зажиточных и богатых представителей общества. Все проводимые в обществе мероприятия интерпретировались как интересы трудового народа, для чего была провозглашена диктатура пролетариата, которая по существу являлась партийной диктатурой.

Новая власть через «кресткомы» и «бедняцкомы» активно привлекала беднейшую часть населения к борьбе с духовенством и зажиточными представителями, тем самым давая им возможность сполна расквитаться за свою бедность. Советская власть ставку делала на «передачу управления селами сельской бедноте и потомкам рабов«хъузхъул», возвысившимся в горском обществе в ущерб правам прежней сельской верхушки. Из худородных тухумов Элигъай вышли первые руководители колхоза и сельсовета Хуштада» [1, с. 20].

Все неудачи по советской модернизации списывались на «контрреволюцию» и «врагов народа», в числе которых в первую очередь оказывались представители духовенства и зажиточные. «Вредительством» и борьбой с «врагами народа» объяснялись политические репрессии в период советской модернизации. Между тем в каждом обществе пассивная, а соответственно, бедная часть населения испытывала ненависть к зажиточным представителям из-за своего низкого социального статуса, чем и пользовалась советская власть при 
репрессиях, интерпретируя это как классовый антагонизм.

Почти поголовно была истреблена едва зародившаяся после революции в Дагестане национальная интеллигенция, а те, кто выжил, вынуждены были мыслить и действовать категориями идеологических установок. Жестокие формы и методы, а также широкие масштабы репрессий обусловили быструю трансформацию общественного сознания народов Дагестана в духе преданности пролетарским идеям.

Пытки в застенках НКВД в период репрессий отличались изощренностью, от многочасовых стоек до избиений в подземной «бане». Внесудебные «тройки» в стране были специально созданы для производства массовых репрессий. В Дагестане от произвола «троек» за полтора года (1937-1938 гг.) по официальным данным пострадали 5 тысяч человек - 2 тыс. погибших и 3 тыс. приговоренных к различным срокам заключения [17, с. 39].

Советская модернизация, которая сопровождалась репрессиями, в Дагестане представляла собой острый и масштабный социальный конфликт между политической системой и человеческой личностью, когда личность подвергалась фризическому и психическому насилию ради реализации политических идей. За каждой сломанной судьбой репрессированного стоят морально-психологические страдания их близких и родных, с учетом которого масштабы репрессий не ограничиваются только числом погибших. Репрессии на десятилетия вперед внедрили психоз и подозрительность в общественное сознание и трансформировали его в русле партийной идеологии. Горская ментальность испытала серьезную трансформацию в том плане, что традиционно присущие горцам морально-этические качества, такие как личное достоинство, прямодушие и другие, подверглись девальвации Отныне человеческая личность стала рассматриваться через призму политической целесообразности, критерием которой стало умение адаптировать мысли и образ жизни под политику партии и официальную идеологию.

Опыт истории, независимо от того, позитивный он или негативный, поучителен, и дагестанский опыт в этом смысле не исключение. Октябрьская революция и социалистическая модернизация обеспечили обществу качественный переход, трансформировали социально-экономический уклад и сознание народов Дагестана из традици- онного в социалистический.

Однако марксистская модель социального устройства, в которую насильственно было загнано общество, оказалась бесперспективной и противоречила объективным законам социально-экономического развития. В период от революции 1917 г. и до 60-х годов население Дагестана испытывало острый десрицит материальных ресурсов, а над обществом витал страх подозрительности и репрессий. Следствием такого положения является то, что в обществе по прошествии более 70 лет происходит социально-экономическая и политическая переструктуризация в русле рыночной экономики, что сопровождается острыми социальными конфликтами.

Резюмируя сказанное, отметим, что Октябрьская революция 1917 г. и обусловленная ею социально-экономическая модернизация в Дагестане имела свою специфику. В числе локальных особенностей следует назвать:

1. Значительное отставание области от промышленных центров России;

2. Острый дефрицит материальных ресурсов и особенно земли;

3. Доминирование в общественном сознании и быту патриархальных порядков, а также полиюридизм в регламентации общественных отношений;

4. Сильные позиции мусульманского духовенства в обществе;

5. Политика «военного коммунизма» и бесчинства частей красной армии.

В совокупности эти причины и сопутствующие им факторы предопределили затяжной и острый характер гражданской войны в области, а также специфику последующих мероприятий по социалистической модернизации общества. Тот фракт, что до революции в Дагестане на почве классового антагонизма не погиб ни один человек, а число погибших в период гражданской войны и социалистической модернизации даже не поддается подсчету, является свидетельством искусственного характера революционных преобразований в области.

Опыт социального устройства по социалистическому принципу показал, что социальная справедливость не достигается посредством национализации земли, экспроприации собственности и ее искусственного перераспределения. Социальная дифференциация - явление объективное и необходимое для социального прогресса.

\section{ЛИТЕРАТУРА}

1. Бобровников В.О. Колхозная метаморфоза сельской общины и власти у малых народов Нагорного Дагестана // Ваш выбор M., 1996, № 3 .

2. Бобровников В.О. Мусульмане Северного Кавказа. Обычай, право, насилие. - М., 2002.

3. Борьба за победу и упрочение Советской власти в Дагестане. Под ред. Аликберова Г.А. - Махачкала, 1960.

4. Борьба за установление Советской власти в Дагестане
1917 - 1921 ге. Сборник материалов и документов. Ответ. Ред. Даниялов Г. - А. Д. М., 1958. Док. № 18.

5. Вагабов М.В. Кара Караев. - Махачкала, 1998.

6. Военный комиссариат горного Дагестана (1920-1921г2.) // ЦГА РД Ф. p-4. Оп. 3. Д. 37.

7. Военный комиссариат горного Дагестана (1920-1921 г2.) // ЦГА РД Ф. p-4. Оп. 2. Д. 54

8. Воспоминания Ибрагима Махмудова «1918 год. К 10-летию 
Советской власти в Дагестане» // Газета «Красный Дагестан» за 1928 г.

9. Газета «Молодежь Дагестана» от 30 мая 2003 г.

10. Гусейнов Г.М. Антисоветское восстание в Западном Дагестане в 1920-1921 ге.: причины, ход и последствия. - Махачкала, 2013.

11. Дагестанский отдел объединенного государственного Политического управления при Совете Народных Комиссаров СССР // ЦГА РД Ф. p-800. Оп. 2. Д. 20.

12. Далгат Э.М. Город и городская жизнь в Дагестане во второй половине XIX - начале XX в. - Махачкала, 2015.

13. Даниялов Г.Д. Социалистические преобразования в Дагестане (1921-1941 ге.) - Махачкала, 1960

14. Записка о политическом положении в Дагестане в период антисоветского мятежа // ЦГА РД Ф. p-41. Оп. 3. Д. 1.

15. Исаев А.А. Магомедмирза Мавраев - первопечатник и просветитель Дагестана. - Махачкала, 2003.

16. История Дагестана с древнейших времен до наших дней. В двух томах. - Махачкала, 2005. Т. 2

17. Какагасанов Г.И. Репрессии 30-х годов в Дагестане: истоки и практика (вместо введения) // Репрессии 30-х годов в Дагестане (Документы и материалы). Ответ. ред. Османов А.И. - Махачкала, 1997.

18. Коллективизация и антиколхозные выступления в Дагестане (1927-1940г2.) // Документы и материалы (сост. Кака- гасанов Г.И.). - Махачкала, 2007.

19. Корнилов Г.Е. Бедность как образ жизни: уральская деревня в военные и послевоенные годы (1941-1953) // Уральский исторический вестник. № 3 (40) Екатеринбург, 2013.

20. Омаров А. Как живут лаки (Из воспоминаний детства) // ССКГ. Вып. ІІІ. Тифрлис, 1870.

21. Османов А.И. Дагестан в XX веке: исторический опыт регионального развития. В 2-х книгах // Общественно-политическая жизнь и социокультурное развитие народов Дагестана. Книга вторая. - Махачкала, 2008.

22. Пирбудагов Н.П. История становления и развития дагестанской милиции в 20-е годы XX века / Дисс. канд. ист. наук. - Махачкала, 1998.

23. Полевой материал автора. 2008 год.

24. Тахнаева П.И. Аргвани. Мир ушедших столетий. Исторический портрет сельской общины Нагорного Дагестана. - М., 2012.

25.Тахо-Годи А. Революция и контрреволюция в Дагестане. Махачкала, 1927

26. Тахо-Годи А. О нашем свидании с В.И. Лениным // Борьба за Советскую власть в Дагестане. Ответ. - Махачкала, 1957. 27. Тодорский А.И. Красная армия в горах. Действия в Дагестане. - М., 1925

28. Шарль Р. Мусульманское право. - М., 1959.

\section{SPECIFICITY OF CIVIL WAR AND SOVIET MODERNIZATION IN DAGESTAN V.D. Dzidzoev* ${ }^{*}$ K.G. Magomedsalikhov**}

* Dr, professor, North Ossetian State University named after K.L. Khetagurova, Gorsky State Agrarian University, Vladikavkaz Scientific Centre, Russian Academy of Sciences (dzidzoevv@mail.ru) ** Dr, Professor, Institute of History, Archaeology and Ethnography of the Daghestan Scientific Center of the Russian Academy of Sciences, Makhachkala (Haibula45@mail.ru).

Abstract. The October revolution of 1917 and the subsequent socio-economic and political modernization in Dagestan had its own specific features resulting from local causes and factors. Accordingly the civil war in the Region had a protracted nature, and became an acute social conflict. Soviet modernization was accompanied by political repression. Keywords: Dagestan, revolution, civil war, anti-Soviet uprising, Soviet modernization, collectivization.

\section{REFERENCES}

1. Bobrovnikov V.O. Kolhoznaya metamorfoza sel'skoj obshchiny i vlasti u malyh narodov Nagornogo Dagestana // Vash vybor M., 1996, № 3.

2. Bobrovnikov V.O. Musul'mane Severnogo Kavkaza. Obychaj, pravo, nasilie. - M., 2002.

3. Bor'ba za pobedu i uprochenie Sovetskoj vlasti v Dagestane. Pod red. Alikberova G.A. - Mahachkala, 1960.

4. Bor'ba za ustanovlenie Sovetskoj vlasti v Dagestane 1917 - 1921 gg. Sbornik materialov i dokumentov. Otvet. Red. Daniyalov G. - A. D. M., 1958. Dok. № 18 .

5. Vagabov M. V. Kara Karaev. - Mahachkala, 1998.

6. Voennyj komissariat gornogo Dagestana (1920-1921gg.) // CGA RD F. r-4. Op. 3. D. 37

7. Voennyj komissariat gornogo Dagestana (1920-1921 gg.) // CGA RD F. r-4. Op. 2. D. 54.

8. Vospominaniya Ibragima Mahmudova "1918 god. K 10-letiyu Sovetskoj vlasti v Dagestane» // Gazeta «Krasnyj Dagestan» za $1928 \mathrm{~g}$

9. Gazeta «Molodezh' Dagestana» za 30 maya $2003 \mathrm{~g}$.

10. Gusejnov G.M. Antisovetskoe vosstanie v Zapadnom Dagestane v 1920-1921 gg.: prichiny, hod i posledstviya. - Mahachkala, 2013.

11. Dagestanskij otdel ob»edinennogo gosudarstvennogo Politicheskogo upravleniya pri Sovete Narodnyh Komissarov SSSR // CGA RD F r-800. Op. 2. D. 20

12. Dalgat EH.M. Gorod i gorodskaya zhizn'v Dagestane vo vtoroj polovine XIX - nachale XX v. - Mahachkala, 2015.

13. Daniyalov G.D. Socialisticheskie preobrazovaniya v Dagestane (1921-1941 gg.) - Mahachkala, 1960.

14. Zapiska o politicheskom polozhenii v Dagestane v period antisovetskogo myatezha // CGA RD F. r-41. Op. 3. D. 1.

15. Isaev A.A. Magomedmirza Mavraev - pervopechatnik i prosvetitel' Dagestana. - Mahachkala, 2003.

16. Istoriya Dagestana s drevnejshih vremen do nashih dnej. V dvuh tomah. - Mahachkala, 2005. T. 2.

17. Kakagasanov G.I. Repressii 30-h godov v Dagestane: istoki i praktika (vmesto vvedeniya) // Repressii 30-h godov v Dagestane (Dokumenty i materialy). Otvet. red. Osmanov A.I. - Mahachkala, 1997.

18. Kollektivizaciya $i$ antikolhoznye vystupleniya v Dagestane (1927-1940gg.) // Dokumenty i materialy (sost. Kakagasanov G.I.). Mahachkala, 2007.

19. Kornilov G.E. Bednost' kak obraz zhizni: ural'skaya derevnya v voennye i poslevoennye gody (1941-1953) // Ural'skij istoricheskij vestnik. № 3 (40) Ekaterinburg, 2013.

20. Omarov A. Kak zhivut laki (Iz vospominanij detstva) // SSKG. Vyp. III. Tiflis, 1870.

21. Osmanov A.I. Dagestan v XX veke: istoricheskij opyt regional'nogo razvitiya. V 2-h knigah // Obshchestvenno-politicheskaya zhizn' $i$ sociokul'turnoe razvitie narodov Dagestana. Kniga vtoraya. - Mahachkala, 2008.

22. Pirbudagov N.P. Istoriya stanovleniya i razvitiya dagestanskoj milicii v 20-e gody XX veka / Diss. kand. ist. nauk. - Mahachkala, 1998 23. Polevoj material avtora. 2008 god.

24. Tahnaeva P.I. Argvani. Mir ushedshih stoletij. Istoricheskij portret sel'skoj obshchiny Nagornogo Dagestana. - M., 2012.

25. Taho-Godi A. Revolyuciya i kontrrevolyuciya v Dagestane. - Mahachkala, 1927.

26. Taho-Godi A. O nashem svidanii s V.I. Leninym // Bor'ba za Sovetskuyu vlast'v Dagestane. Otvet. - Mahachkala, 1957.

27. Todorskij A.I. Krasnaya armiya v gorah. Dejstviya v Dagestane. - M., 1925.

28. SHarl'R. Musul'manskoe pravo. - M., 1959. 